\title{
UTE (Ular Tangga Edukatif ) : Permainan Edukatif Matematika Berbasis Kearifan Lokal Sebagai Upaya Menciptakan Penunjang Pembelajaran yang Menyenangkan dalam Menghadapi Revolusi Industri 4.0
}

\author{
Elis Yuningsih 1, Siti Julaeha 2, Badilah Bin Rawin ${ }^{3}$ \\ ${ }^{1}$ Mahasiswa (Fakultas FKIP, Universitas Swadaya Gunung Jati) \\ 2 Mahasiswa (Fakultas FKIP, Universitas Swadaya Gunung Jati) \\ ${ }^{3}$ Mahasiswa (Fakultas FKIP, Universitas Swadaya Gunung Jati) \\ Email : Elisyuningsih99@gmail.com
}

\begin{abstract}
Abstrak - Saat ini kualitas pendidikan di Indonesia masih sangat rendah. Sebuah studi terbaru (Amanda dkk, CFEE Annual Digest 2018) menyatakan bahwa selama sekian tahun sejak masuk SD hingga lulus SMA sekolah hanya meningkatkan keterampilan menghitung atau aritmatika sederhana dari peserta didik sebanyak nol koma nol sekian persen. Rendahnya kemampuan matematika siswa tersebut karena kurangnya latihan pengerjaan soal yang beragam sehingga apa yang diterangkan oleh guru tidak dapat dipahami sepenuhnya oleh siswa. Disamping itu, sifat anak anak yang pantang menyerah dan masih haus akan bermain membuat siswa kekurangan waktu belajar. Untuk mengatasi permasalahan tersebut, peneliti menciptakan sebuah penunjang pembelajaran matematika berupa permainan Ular Tangga Edukasi (UTE) yang diharapkan dapat membantu para siswa melakukan melakukan kegiatan bermain dan belajar dengan soal-soal matematika yang ada pada desain permainan tersebut.
\end{abstract}

Kata kunci: Permainan, Hasil Belajar, UTE 


\section{PENDAHULUAN}

Saat ini kualitas pendidikan di Indonesia masih sangat rendah. Sebuah studi terbaru (Amanda dkk, CFEE Annual Digest 2018) yang menyatakan bahwa anak muda Indonesia akan siap menghadapi abad ke-21, ketika abad ke-31 menjelang, studi tersebut menghitung bahwa selama sekian tahun sejak masuk SD hingga lulus SMA sekolah hanya meningkatkan keterampilan menghitung atau aritmatika sederhana dari peserta didik sebanyak nol koma nol sekian persen.

Dengan merujuk ke hasil uji PISA (Program for International Student Assesement) dan uji TIMSS (Trend for International Mathematic and Sciences Study) ketika peringkat siswa Indonesia kelas $2 \mathrm{SMP} / \mathrm{MTs}$ hanya selapis di atas Bostwana Afrika. Indonesia menempati peringkat ke-64 dari 65 negara. Hasil studi ini menunjukan bahwa kemampuan matematika siswa di Indonesia masih belum baik.

Hasil penelitian Suryanto dan Somerset (dalam Zulkardi, 2001) terhadap 16 SLTP pada beberapa propinsi di Indonesia menunjukkan bahwa hasil tes mata pelajaran matematika siswa sangat rendah, terutama pada soal cerita matematika (aplikasi matematika). Demikian juga dengan hasil penelitian Suryadi (2005) terhadap siswa kelas dua SMP di kota dan kabupaten Bandung yang menemukan bahwa mereka mengalami kesulitan dalam mengajukan argumentasi, menemukan pola dan pengajuan bentuk umumnya. Rendahnya kemampuan matematika siswa tersebut karena kurangnya latihan pengerjaan soal yang beragam sehingga apa yang diterangkan oleh guru tidak dapat dipahami sepenuhnya oleh siswa. .

Disamping itu, sifat anak anak yang pantang menyerah dan masih haus akan bermain membuat siswa kekurangan waktu belajar. Siswa lebih cenderung banyak waktu bermain dari pada belajar. Untuk mengatasi permasalahan tersebut, peneliti menciptakan sebuah penunjang pembelajaran matematika berupa permainan Ular Tangga Edukasi (UTE) yang diharapkan dapat membantu para siswa bermain sambil belajar dengan soal-soal matematika yang ada pada desain permainan tersebut.

Tujuan dalam penelitian ini Untuk (1) menciptakan desain permainan edukatif berupa UTE (Ular tangga Edukatif) (2) Untuk Menganalisis Apakah Desain UTE dapat meningkatkan Hasil belajar siswa (3) Untuk menganalisis Apakah desain UTE dapat digunakan sebagai media pembelajaran.

Adapun manfaat penelitian ini (1) Untuk Sekolah Desain UTE dapat digunakan sebagai Penunjang Pembelajaran (2) Untuk Siswa Desain UTE dapat dimanfaatkan sebagai ajang belajar dan bermain (3) Manfaat social Dengan bermain UTE dapat menghindarkan suasana kebersamaan antar siswa. (4) Manfaat Ekonomis UTE dapat menggantikan permainan digital (online) sehingga dapat menghemat kuota internet

\section{KAJIAN LITERATUR}

Permainan (games) adalah setiap kontes antara pemain yang berinteraksi satu sama lain dengan mengikuti aturan-aturan tertentu untuk mencapai tujuan tertentu pula (Sadiman dalam Yumarlin, 2013: 76). Permainan sangat identik dengan kegiatan anak-anak, dengan begitu maka pengertian permainan adalah suatu media interaksi anak-anak yang dibubuhi dengan aturan dan hal-hal yang menyenangkan dalam mencapai tujuan tertentu. Permainan tidak lepas dari alat penunjangnya. Menurut Yumarlin 
(2013: 76-77) Alat permainan adalah semua alat bermain yang dapat digunakan oleh peserta didik untuk memenuhi naluri bermainnya dan memiliki barbagai macam sifat, seperti bongkar pasang, mengelompokkan, memadukan, mencari padanannya, merangkai, membentuk, atau menyusun sesuai dengan bentuk aslinya. Jadi, dapat disimpulkan bahwa alat permainan sangat berpengaruh penting terhadap permainan yang dilakukan oleh anak-anak.

Salah satu permainan yang banyak digemari anak-anak adalah permainan ular tangga. Permainan ular tangga adalah permainan papan untuk anakanak yang dimainkan oleh dua orang atau lebih (Novitasari, 2013: 41). Papan permainan ular tangga dibagi dalam kotak-kotak kecil dan beberapa kotak digambar sejumlah "tangga" atau "ular" yang menghubungkannya dengan kotak lain. Permainan ini diciptakan pada tahun 1870. Tidak ada papan permainan standar dalam ular tangga, jadi setiap orang dapat menciptakan ukuran papan permainan ular tangga, dengan jumlah kotak, ular, dan tangga sesuai yang diinginkan.

Seperti Permainan Matematika, Permainan Ular Tangga mengajarkan konsep angka dan bilangan, anak bisa berlatih berhitung, belajar teliti dari menyesuaikan jumlah mata dadu dengan pergerakan bidak, disiplin dari menunggu giliran menjalankan bidak dan membangun percaya diri dalam berhitung yang menjadi dasar bagi anak mengembangkan kemampuan matematikanya.

Ular Tangga Edukasi (UTE) merupakan permainan yang peneliti kembangkan dari permainan ular tangga biasa menjadi jenis permainan yang memiliki nilai edukasi. Desain ini dibuat berbeda dengan menyisipkan soal Matematika dibawah tangga dan di ujung ekor ular sebagai syarat untuk menjalankan fungsi ular atau tangga agar dapat naik atau turun seperti permainan ular tangga pada umumnya. Ketika sang pemain berada di bawah tangga maka harus bisa menjawab kartu soal agar bisa menaiki tangga tersebut, sebaliknya jika sang pemain menginjak kepala ular maka harus dapat menjawab pertanyaan yang ada pada kartu soal agar berhasil selamat dari jebakan ular. Dengan adanya pertanyaan tersebut diharapkan para pemain tertantang dan tidak terasa bahwa sebenarnya mereka sedang melakukan permainan sambil belajar matematika.

Yang berbeda lagi dari Desain UTE ini adalah kotak istimewa dan kotak hukuman, kotak ini sebagai reward bagi pemain yang beruntung berhenti dikotak tersebut, dan merupakan sebuah petaka bagi pemain yang tidak beruntung yang menempati kotak tersebut.

Desain yang dibuat juga menggambarkan kebudayaan yang berkembang dikota Cirebon dan sekitarnya seperti tari topeng, jaipong, kuda lumping, dan lain lain sebagai bentuk pelestarian budaya bangsa yang semakin hari semakin luntur keberadaannya.

\section{METODE PENELITIAN}

Tahapan atau alur pada penelitian ini mengikuti prosedur yang dikemukakan Roiser dan Molenda (Tegeh dan Irna : 2013), model ADDIE, yang terdiri atas lima langkah yaitu: (1) Analyze, (2) Design, (3) Development, (4) Implementation, dan (5) Evaluation.

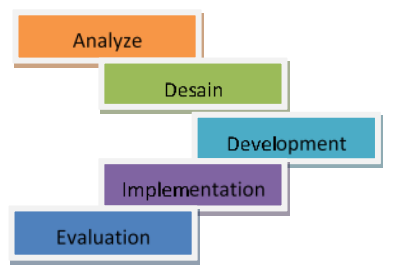

Tabel. 1 Tahapan penelitian 


\section{HASIL DAN PEMBAHASAN}

\section{Analisis}

Berdasarkan hasil analisis yang dilakukan, peneliti menemukan rendahnya nilai matematika pada nilai Ujian Nasional di berbagai daerah. Penunjang pembelajaran sangat dibutuhkan untuk memberikan pemahaman yang lebih terhadap materi atau soal yang diajarkan oleh guru di sekolah. Oleh karena itu kami menciptakan media berupa permainan edukasi UTE (Ular Tangga Edukasi) sebagai penunjang pembelajaran matematika.

\section{Tahap Desain}

Peneliti merancang dan membuat sedemikian rupa desain permainan ular tangga edukasi dengan menggunakan aplikasi photoshop.

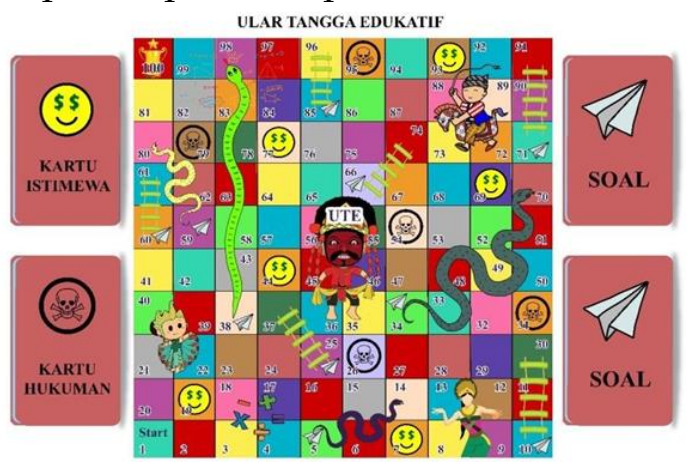

Gambar.1 Desain Papan Ular tangga edukatif

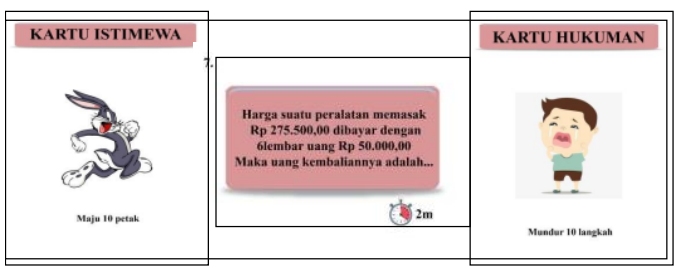

Gambar.2 Desain Kartu istimewa, Kartu soal dan kartu hukuman

\section{Tahap Development}

Dalam desain yang peneliti rangcang, terdapat beberapa peraturan peraturan yang sedikit berbeda yang peneliti kembangkan dari permainan ular tangga pada umumnya. Dalam permainan UTE ini peneliti menyisipkan soal soal matematika sebagai perangkat permainan. Hal ini dimaksudkan agar siswa dapat lebih mengasah soal matematika dengan konsep menarik yaitu belajar dan bermain.

\section{Tahap Implementation}

Tahap implementasi meliputi Uji coba game serta tahap dimana peneliti memperoleh data. Hasil yang diperoleh dari penelitian yang dilakukan di SDN Leuwidingding kecamatan Lemahabang Kabupaten cirebon dalam tahap implementasi permaian UTE ini adalah sebagai berikut:

\section{Perbandingan Tes Matematika}

\begin{tabular}{|l|c|c|c|}
\hline Sample & Pre-Test & Post-Test & Peningkatan \\
\hline $\begin{array}{l}\text { Kelas } \\
\text { IV }\end{array}$ & 64 & 78 & $21,9 \%$ \\
\hline Kelas V & 69 & 84 & $17,8 \%$ \\
\hline $\begin{array}{l}\text { Kelas } \\
\text { VI }\end{array}$ & 72 & 86 & $19,4 \%$ \\
\hline
\end{tabular}

Tabel.2 Hasil Perbandingan Tes Matematika

Berdasarkan hasil penelitian, rata- rata kelas sampel mengalami peningkatan setelah melakukan proses Gaming. Peningkatan tertinggi terjadi dikelas IV yaitu sebesar 21,9 \% peningkatan terendah terjadi di kelas $\mathrm{V}$ dengan 17,8 $\%$.

\section{Kuisioner}

Dari 46 responden yang terdiri dari 3 jenjang kelas berdasarkan hasil analisis kuisioner menunjukan bahwa:

\begin{tabular}{|l|c|c|}
\hline Sample & $\begin{array}{c}\text { Kepuasan } \\
\text { setelah } \\
\text { Gaming(\%) }\end{array}$ & $\begin{array}{c}\text { Penilaian } \\
\text { Konten } \\
\text { Game } \\
(\%)\end{array}$ \\
\hline Kelas IV & 90 & 92 \\
\hline Kelas V & 86 & 84 \\
\hline Kelas VI & 80 & 85 \\
\hline
\end{tabular}


Tabel.3 Data Hasil Olahan Kuisioner

Berdasarkan hasil kuisioner, diperoleh kategori kepuasan terhadap proses gaming dan penilaian terhadap Game UTE cukup positif, dari sample kelas IV kepuasan setelah Gaming dan penilaian terhadap konten Game menjadi yang tertinggi dengan $90 \%$, dan $92 \%$. Sementara penilaian sample terendah untuk kategori Kepuasan setelah Gaming yakni pada sample kelas VI yakni sebesar $80 \%$. Sedangkan untuk kategori penilaian terhadap konten game terendah terjadi pada kelas $\mathrm{V}$ yaitu sebesar $84 \%$.

\section{Tahap Evaluation}

Dari hasil uji coba game, desain game Ular Tangga Edukasi UTE ini memiliki kelebihan dan kekurangan diantaranya:

Kelebihan
a. UTE adalah Media penunjang pembelajaran yang menarik
b. Mampu mengasah kemampuan matematika siswa
c. Melestarikan permainan Tradisinal

Kekurangan
a. Permainan memerlukan waktu terlalu lama
b. hanya bisa dimainkan untuk siswa yang satu kelas (beda tingkatan kelas maka berbeda pula tingkat kesulitan soal)

\section{Manfaat Permainan UTE}

Permainan UTE dapat mendorong siswa untuk mengurangi penggunaan game yang ada pada gadget, sehingga risiko kerusakan pada mata akibat penggunaan gadget dapat berkurang. Selain itu, siswa dapat melakukan permainan sambil belajar karena permainan ini didesain dengan ditambahkan soal matematika didalamnya.

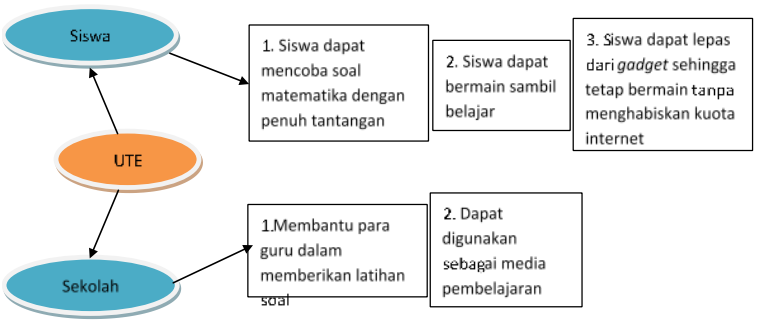

Tabel.4 Manfaat Permainan UTE

\section{KESIMPULAN}

Ular Tangga Edukasi (UTE) merupakan permainan yang peneliti kembangkan dari permainan ular tangga biasa menjadi jenis permainan yang memiliki nilai edukasi. Tujuan dari diciptakannya permainan ini agar para pemain (Siswa) tertantang dan tidak terasa bahwa sebenarnya mereka sedang melakukan permainan sambil belajar matematika. Terlihat dari hasil Penelitian didapatkan bahwasanya desain UTE dapat meningkatkan hasil belajar siswa pada mata pelajaran matematika.

Lebih jauh lagi Desain yang dibuat juga menggambarkan kebudayaan yang berkembang dikota Cirebon dan sekitarnya seperti tari topeng, jaipong, kuda lumping, dan lain lain sebagai bentuk pelestarian budaya bangsa yang semakin hari semakin luntur keberadaannya.

UTE dapat diterapkan pada media pembelajaran dengan catatan guru dapat membatasi waktu permainan sesuai kebutuhan.

\section{REFERENSI}

Novitasari, Erma. 2013. Pengembangan Media Pembelajaran Berbasis IT Berbentuk Permainan Ular Tangga Materi Alat Optik untuk Kelas VIII SMP. Jurnal Pendidikan Fisika. 1(1), 37-45.

Rizali, Ahmad. 2016. Indonesia Darurat Matematika. Tersedia [Online]: https://edukasi.kompas.com/r ead/2018/09/24/07200071/ind 
onesiadarurat-

matematika?page $=$ all.

September 2018).

Suryadi, Didi (2005) Penggunaan Pendekatan Pembelajaran Tidak Langsung Serta Pendekatan Gabungan Langsung dan Tidak Langsung Dalam Rangka Meningkatkan Kemampuan Berpikir Matematik Tingkat Tinggi Siswa Sltp.

eprint_fieldopt_thesis_type_phd thesis, Universitas Pendidikan Indonesia.

Yumarlin. 2018. Pengembangan Permainan Ular Tangga untuk Kuis Mata Pelajaran Sains Sekolah Dasar. Jurnal Teknik. $3(1), 75-84$.

Zulkardi. (2001). Realistic Matematics Education (RME). Teori. Contoh Pembelajaran dan Taman Belajar di Internet. Makalah: UPI Bandung. 